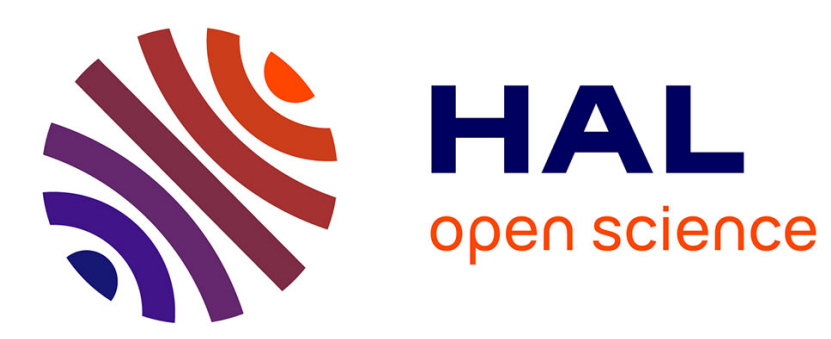

\title{
Towards a more coherent oil policy in Russia?
}

Sadek Boussena, Catherine Locatelli

\section{- To cite this version:}

Sadek Boussena, Catherine Locatelli. Towards a more coherent oil policy in Russia?. Opec Review, 2005, XXIX (2), pp.85-105. halshs-00003970

\section{HAL Id: halshs-00003970 https://shs.hal.science/halshs-00003970}

Submitted on 20 Jun 2005

HAL is a multi-disciplinary open access archive for the deposit and dissemination of scientific research documents, whether they are published or not. The documents may come from teaching and research institutions in France or abroad, or from public or private research centers.
L'archive ouverte pluridisciplinaire HAL, est destinée au dépôt et à la diffusion de documents scientifiques de niveau recherche, publiés ou non, émanant des établissements d'enseignement et de recherche français ou étrangers, des laboratoires publics ou privés. 


\title{
Towards a more coherent oil policy in Russia?
}

\author{
S. Boussena, \\ Professor, University of Grenoble II, former Algerian Minister of Energy, \\ and C. Locatelli, \\ Research Fellow, CNRS, LEPII-EPE, University of Grenoble II.
}

January 2005

Two recent trends have rekindled the debate concerning the place and strategy of Russia on the world oil scene. The first is the development of its oil production (over $9 \mathrm{Mb} / \mathrm{d}$ in 2004) and the second is the gradual resumption of control of the country's oil policy by Vladimir Putin's government. Will Russia be a key variable in world energy balances? Could Russia as some suggest and even desire - become an alternative source of supply to OPEC and/or challenge Saudi Arabia's position? And if so, is this what Russia wants? Without underestimating the development potential of the hydrocarbon sector (and gas in particular) but without, at the same time, being overawed by the spectacular increase in the country's oil production - which for the moment is no more than a return to the output levels of the 1980s this question can be answered only by assessing and comparing the capabilities of the two countries to meet world oil demand growth. In other words, the challenge concerns their capacity for increasing exports in order to meet additional demand over a long period of time.

Being the world's largest oil producer for a certain period of time does not automatically make Russia competitive with Saudi Arabia on the world market. Two important questions must be considered here. Can Russia increase its output on a long-term basis? And is it able to have the spare capacity that it would need to influence prices? While increases in OPEC production are governed essentially by legal and geopolitical aspects, in Russia's case there are also other constraints related to the estimation of reserves, real production costs and the evolution of domestic demand.

In fact, Russia's hesitation in adopting a clear position with regard to OPEC (and its price policy), which has been evident since 2001, simply reflects the country's desire for an oil strategy that is better suited to its domestic situation and the new international context. In contrast with the last ten years, Russia now intends to harmonise its oil policy in accordance with its actual means and the economic and institutional constraints of its transition to a market economy.

A comparative analysis of Russia's performance on the world scene supported by information regularly updated by experts indicates that while Russia can still play an important role it cannot, in the longer term, compete with OPEC and more specifically with Saudi Arabia. But setting aside its physical incapacity to compete with OPEC in the long term, it would appear that Russia has no such a goal in mind. The growing attention being paid by the Russian authorities to the oil sector should therefore not be interpreted as a desire to compete with OPEC, but rather as a strategy aimed at using Russia's oil power not only for economic ends but also as an additional instrument in its foreign and international bargaining policy.

This policy, if it is to be coherent, must be based on one of two "polar" models. The first we might call the "Norwegian model" and the second the "OPEC model". In the first, the hydrocarbons sector remains important but is not considered a fundamental factor in economic growth. In the "OPEC model”, however, the hydrocarbons sector is the principal 
(even the only) source of external revenue and the State tends to use it as an instrument to reach other goals, notably in economic development or redistribution of revenues. The position of Russia in regard to OPEC is, in part, the result of choices between these two options. While its professed aim is a market economy, suggesting the "Norwegian model", failure of reforms seems to be inducing the Russian authorities to use the oil and gas industry for economic and social restructuring purposes and also as a lever in their international policy. This does not necessarily mean that the privatisation process is being called into question, but there may be a move toward a type of state control based on strong public sector participation combined with private capital close to the centres of power and, if necessary, on foreign companies willing to accept minority shares in the entities that are set up. In such a perspective, what might be the weight and strategy of Russia in a world oil market?

\section{Production and Exports: considerable differences between estimates.}

Russia's place in the international oil market will depend on its export levels and thus on future production.

\section{- Production forecasts for 2010}

For the time being, and apparently for a few years to come, additional non-OPEC production will come essentially (80\% for 2000-2003) from the former Soviet Union (Russia and Caspian region), to the point where certain analysts believe that Russia (alone responsible for $79 \%$ of this share) could counterbalance the influence of OPEC. Forecasts for 2010 vary considerably, ranging from 6 to $12 \mathrm{Mb} / \mathrm{d}$. The most optimistic indicate that Russia's record level of 1987 (11.4 Mb/d) could be reached by 2008/2010. But more sceptical analysts forecast slower growth, given that the factors that have promoted the rise over the last five years are gradually disappearing. In such a situation, growth of production capacity would be strongly dependent on exploration and development investments in the new regions. The lowest estimates come from certain Russian agencies including the Ministry of Foreign Affairs (5.6 Mb/d) while the highest have been made by private oil companies and some Western experts (11-12 Mb/d). Between these two extremes there is the "moderate" scenario in which output is estimated at between 8 and $9.6 \mathrm{Mb} / \mathrm{d}$, the upper limit of this range being today's level. Thus, in the recent version of the government's long term energy plan, 2020, (May 2003), the upper limit of this estimate is considered optimistic. It is based on a hypothetical oil price of over $30 \$ / \mathrm{b}$. In the "low scenario" corresponding to prices of less than $30 \$ / \mathrm{b}$, output could drop to $7.2 \mathrm{Mb} / \mathrm{d}$ by 2010 or even to $5.6 \mathrm{Mb} / \mathrm{d}$ if efforts to renew reserves are not implemented. The IEA in its most recent forecasts (October 2004) estimates an output of $10.4 \mathrm{Mb} / \mathrm{d}$ by 2010, with this figure remaining more or less stable until 2020 (10.6 Mb/d). This is an upward revision of its previous estimates (2002). For such a relatively short term, it is surprising that such uncertainties still persist.

Estimates of Russian oil production $\mathrm{Mb} / \mathrm{d}$

\begin{tabular}{|c|c|c|c|c|c|c|}
\hline & & 2003 & 2007 & 2010 & 2015 & 2020 \\
\hline \multirow{2}{*}{$\begin{array}{ll}\text { Russian } & \text { oil } \\
\text { companies } & \end{array}$} & TNK & 8.5 & 10.0 & 11.1 & & \\
\hline & Yukos & 8.5 & $\begin{array}{c}9.0 \\
(2005)\end{array}$ & 11.0 & & 11.0 \\
\hline
\end{tabular}




\begin{tabular}{|c|c|c|c|c|c|c|}
\hline \multirow[t]{2}{*}{$\begin{array}{ll}\text { Long } & \text { term } \\
\text { energy } & \text { plan: } \\
2003 & \end{array}$} & $\begin{array}{l}\text { High } \\
\text { scenario } \\
\text { (1) }\end{array}$ & 8.5 & & $9-9.8$ & 10.17 & $9-10.4$ \\
\hline & $\begin{array}{l}\text { Low } \\
\text { scenario }\end{array}$ & 8.5 & & 7.2 & & 6.3 \\
\hline $\begin{array}{ll}\text { Long } & \text { term } \\
\text { energy } & \text { plan: } \\
2000 & \end{array}$ & & 8.5 & & 6.1-6.7 & $6.1-6.9$ & $6.1-7.2$ \\
\hline $\begin{array}{l}\text { Ministry of } \\
\text { Energy:2000 }\end{array}$ & & & & & 8.0 & \\
\hline \multirow[t]{2}{*}{$\begin{array}{l}\text { Ministry of the } \\
\text { Economy: } 2004\end{array}$} & $\begin{array}{l}\text { Optimisti } \\
\text { c } \\
\text { scenario }\end{array}$ & & $\begin{array}{c}9.14 \\
(2006)\end{array}$ & & & \\
\hline & $\begin{array}{l}\text { Pessimisti } \\
\text { c scenario }\end{array}$ & & $\begin{array}{c}5.62 \\
(2006) \\
\end{array}$ & & & \\
\hline $\begin{array}{l}\text { Ministry of } \\
\text { Natural } \\
\text { Resources: } 2002\end{array}$ & & 8.5 & & & & 5.0 \\
\hline $\begin{array}{l}\text { Ministry of } \\
\text { Foreign Affairs: } \\
2002\end{array}$ & & 8.5 & 9.0 & 5.6 & 5.6 & \\
\hline \multirow{8}{*}{$\begin{array}{l}\text { Independent } \\
\text { experts }\end{array}$} & $\begin{array}{l}\text { Troika } \\
\text { Dialog } \\
\text { (2003) }\end{array}$ & 8.5 & 10.2 & 10.9 & & \\
\hline & $\begin{array}{l}\text { Laherrère } \\
\text { (2002) }\end{array}$ & 8.5 & $\begin{array}{l}7.7 \\
(2008)\end{array}$ & & & 5.0 \\
\hline & $\begin{array}{l}\text { OWEM } \\
\text { model } \\
(2002)\end{array}$ & 8.5 & & 8.2 & & 8.7 \\
\hline & $\begin{array}{l}\text { ASPO } \\
(2003)\end{array}$ & 8.5 & & 9.34 & & 4.85 \\
\hline & $\begin{array}{l}\text { Khartuko } \\
\text { v (2003) }\end{array}$ & & 9.8-10.0 & $\begin{array}{l}11.8- \\
12.1 \\
\end{array}$ & & \\
\hline & $\begin{array}{l}\text { CGES } \\
(2004), \\
(2) \\
\end{array}$ & & $\begin{array}{l}10 \\
(2006)\end{array}$ & 12.0 & 13.0 & \\
\hline & $\begin{array}{l}\text { Woodmac } \\
\text { basic } \\
\text { scenario }\end{array}$ & & & 10.38 & 9.09 & 7.41 \\
\hline & $\begin{array}{l}\text { Woodmac } \\
\text { high } \\
\text { scenario, } \\
\text { (3) }\end{array}$ & & & 12.04 & 10.66 & 8.69 \\
\hline $\begin{array}{l}\text { International } \\
\text { agencies }\end{array}$ & $\begin{array}{l}\text { IEA, } \\
\text { WEO } \\
(2004)\end{array}$ & & & 10.40 & & 10.60 \\
\hline
\end{tabular}

(1) With a price above 30\$/barrel; (2) CGES: Centre for Global Energy Studies. These estimates are based on an international oil price of above 20\$/barrel; (3) In this scenario, there are no constraints.

Sources: Annual reports of various Russian oil companies; The Moscow Times, different years, Fontaine (J-M.), Laherrère (J.), Perrodon (A.).- "Le rebond de la production pétrolière en Russie: Quelles perspectives à long terme? Quelles opportunités industrielles ?" - Revue de l'Energie, n 538, July-August 2002, p. 421-432; "World Energy Investment Outlook 2002".- IEA-OECD, 2002; "Putin seizes Yukos shares; Yukos names new CEO" OGJ, 10 November 2003; Khartukov (E.), Starostina (E.).- "Ex-Soviet Oil Exports: Are the Russians really Coming” - MEES 47:4, 26 January 2004, 10 p. 


\section{- Effects on crude export levels}

These production scenarios imply various possible export levels of crude oil. And it is exports that are the decisive variable for maintaining a sound balance on the international market. At one extreme, we find the most optimistic export forecast of $7 \mathrm{Mb} / \mathrm{d}$ (Khartukov, 2003) ${ }^{1}$ and at the other a forecast of no more than $5.5 \mathrm{Mb} / \mathrm{d}$ in 2010. Despite the considerable difference between these two estimates, they both represent a marked increase compared with current export levels. According to these projections, exports would account for between $50 \%$ and $60 \%$ of output compared with less than $45 \%$ at present. Such a rise in exports would not be compatible with the trend toward greater domestic consumption linked to predicted economic growth. In fact, according to the World Bank, for the next 5 to 10 years, there are unlikely to be drastic changes in the structure of the national economy. If there is an economic recovery, it will be accompanied by a rise in household income leading to transport development and a consequential rise in fuel consumption. According to the IEA, transport demand should increase by $2 \%$ per year between now and $2030^{2}$. If these hypotheses are confirmed, exports of oil and oil products will be lower than the levels projected in the above scenarios. How can these divergences be explained for such short-term projections?

\section{Oil export forecasts}

$\mathrm{Mb} / \mathrm{d}$

\begin{tabular}{|c|c|c|c|c|c|c|}
\hline & & 2005 & 2006 & 2010 & 2015 & 2020 \\
\hline \multirow[b]{2}{*}{$\begin{array}{l}\text { Khartukov } \\
2003 \\
\text { published in } \\
\text { Petrostrategi } \\
\text { es }\end{array}$} & $\begin{array}{c}\text { Likely } \\
\text { scenario }\end{array}$ & 6.2 & & 7.0 & 7.0 & \\
\hline & $\begin{array}{c}\text { Exports } \\
\text { unchanged }\end{array}$ & 5.6 & & 5.6 & 5.6 & \\
\hline $\begin{array}{l}\text { Khartukov } \\
2003\end{array}$ & & $\begin{array}{l}5.0-5.2 \\
(2007)\end{array}$ & & $7.0-7.2$ & & \\
\hline $\begin{array}{l}\text { Long term } \\
\text { plan: } 2002\end{array}$ & & & & 5.0 & & 3.36 \\
\hline $\begin{array}{l}\text { Long term } \\
\text { plan: } 2003\end{array}$ & & & & & & 4.6 \\
\hline $\begin{array}{l}\text { Wood } \\
\text { Mackenzie }\end{array}$ & $\begin{array}{c}\text { Basic } \\
\text { scenario }\end{array}$ & 5.6 & 5.8 & 5.9 & & \\
\hline IEA. 2003 & & & & 5.5 & & 5.3 \\
\hline Transneft & & 4.8 & & & & \\
\hline
\end{tabular}

\footnotetext{
${ }^{1}$ It is important to note that these export figures were estimated by adding together all the oil pipeline projects without taking into account the decision-making processes of the authorities concerned or the financial aspects of these processes. The Murmansk project, which is far from being finalised, is a case in question.

Cf study by Khartukov (E.), Starostina (E.).- "Ex-Soviet Oil Exports: Are the Russians really Coming”.- MEES 47:4, 26 January 2004, 10 p.

${ }^{2}$ Individual car ownership is extremely low at 119 vehicles per 1000 inhabitants compared with 259 in Poland and 542 in Germany.

“Chapter 9: Russia-An in Depth Study” in World Energy Outlook 2004, draft IEA-OECD, September 2004
} 


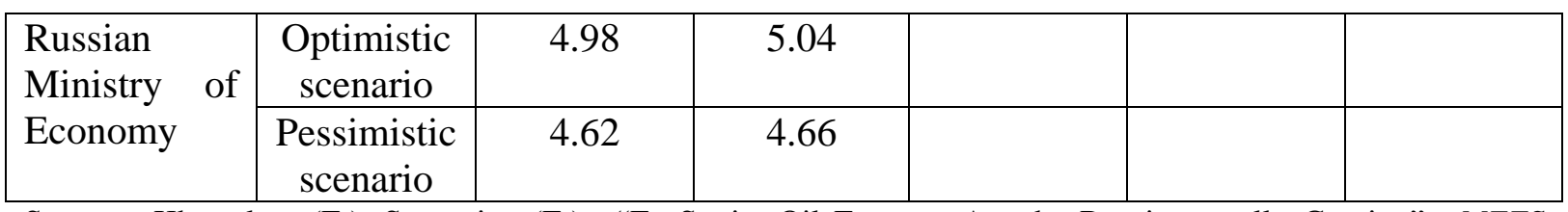

Sources: Khartukov (E.), Starostina (E.).- "Ex-Soviet Oil Exports: Are the Russians really Coming”.- MEES 47:4, 26 January 2004, 10 p; The Moscow Times, different years; "World Energy Investment Outlook 2002".IEA-OECD, 2002; "Putin seizes Yukos shares; Yukos names new CEO" OGJ, 10 November 2003; Pétrostratégies, 10 March 2003, p. 7.

\section{Determinants of future oil output remain uncertain}

Looking beyond the reasons underlying the choice of scenario by the different actors (private companies wishing to maximise output and government ministries promoting exploration), the considerable differences between the various estimates are indicative of the lack of transparency and the uncertainties that still characterise the Russian oil industry. Unlike the gas industry, where differences in estimations have a lesser impact on account of the country's considerable reserves, the poor reliability of oil industry data (reserves, costs, prices, real production capacity, depletion of oil deposits, organisation, tax system, structure of companies' shareholders) exacerbates the lack of clarity surrounding the strategies of actors in a transition context marked by the instability of ownership rights ${ }^{3}$. The future of Russian oil production depends on a number of factors.

\section{- $\quad$ Can the recent rate of increase in production be maintained?}

The sources of the increased productivity in the period 1998-2004, at the origin of the spectacular rise in crude oil production since 2000, might no longer have the same effects in the years to come. For example, the devaluation of the rouble in 1998 went toward improving the profitability of the oil industry. Added to price rises in the same period, this margin enabled Russian oil companies to make considerable investments in enhanced recovery of existing oil deposits and the reopening of wells closed in 1994. (Note that at this time $28 \%$ of Russian oil wells had ceased production). Thus, most of the additional output of the last few years can in fact be attributed to the rehabilitation of existing deposits ${ }^{4}$. While the productivity gains from these re-opened wells cannot be denied, the problem of efficient management of existing reserves must be addressed. In reality, this increase in output seems to have been achieved without any control from the authorities concerning the conservation of deposits.

\section{- Uncertainties surrounding reserves}

One of the greatest unknowns affecting the evolution of Russian oil production concerns reserves. While they are known to be substantial, there is considerable debate as to their estimated volume. Figures range from 48 to 140 billion barrels, depending on the source of

\footnotetext{
3 Tompson (W.).- Putin and the 'Oligarchs' A two-Sided Commitment Problem.- The Royal Institute for International Affairs, Prospects For The Russian Federation Project, REP BN 04/03, August 2004, 16 p.

${ }^{4}$ Over half of the rise in production is attributable to three oil companies, Yukos, Sibneft, Surgutneftegaz, the first two having made huge investments in enhanced oil recovery technologies (hydrofracture, horizontal drilling). “World Energy Investment Outlook 2003”.- IEA-OECD, 2003, p. 148.
} 
information ${ }^{5}$. Problems of management and conservation of deposits must also be addressed, as mentioned above. These problems are a result of the policy of maximum exploitation practised by production associations during the Soviet era and in all likelihood still pursued today. The reluctance of Russian oil companies to invest in exploration in the present phase can only exacerbate the uncertainty surrounding long-term developments in oil production. Indeed, this could explain the sometimes alarmist declarations of certain Russian officials and experts. According to the IEA, $60 \%$ of proven reserves are "difficult to recover" ${ }^{6}$. The low investment in exploration since the beginning of the $1990 \mathrm{~s}^{7}$ raises questions concerning the start of production in new oil-rich areas in light of exhaustion of deposits in the large Western Siberian basins. It is perhaps significant that with the notable exception of Lukoil the main Russian oil majors have, for the most part, increased their reserves through mergers or the acquisition of smaller oil companies ${ }^{8}$.

\section{- “Organisational” uncertainty}

It would appear that the future status of the Russian oil industry has not yet been fully defined. Recent developments suggest there is hesitation between several possibilities ${ }^{9}$. The first possibility would be to put in place a number of state-owned companies that would dominate the sector and serve as a means of extending a centralised policy. The second would involve pursuing the structuring of the sector by developing companies with public, private and foreign capital, an option that would not exclude the possibility of the State keeping a golden share in the main ones. Given that total privatisation is for the time being ruled out, this second option would present the best hope of protecting private ownership rights, essential for the development of long-term investment strategies. So far, privatisation had taken place in an environment characterised by the weakness and opacity of market institutions, opening up little prospect of a model that could be described as an "international oil company". In particular, private groups that had acquired state-owned companies sold off under the Loans for Shares programme in $1995^{10}$ reacted by practising cash stripping (a way

${ }^{5}$ For example, according to BP, Russia's oil reserves are of the order of 60 billion barrels, the OGJ puts the
figure at 48.6 billion barrels, and IHS Energy estimated reserves of 140 barrels at the end of 2001. The USGS
evaluation is 207 billion barrels. Cf. "Saudi Pact Shows Russia's New Strength".- Petroleum Intelligence Weekly, 8 September 2003, p.1-2.

${ }^{6}$ IEA, 2003, op. cit., p. 148.

${ }^{7}$ Investment in exploration in the oil sector a fell by more than 30\% in 2002 compared with 2001. This trend continued in 2003. "Russian Economy: Trends and Perspectives". Institute for The Economy in Transition, Monthly Bulletin, September 2003 and July 2003.

${ }^{8}$ Lukoil has developed a strategy of investment in the exploration of new oil-bearing areas mainly in the North Caspian region and the Timan Pechora basin.

${ }^{9}$ An extremely concentrated industry in which four large private oil companies, Lukoil, Yukos, TNK (now TNK-BP) and Surgutneftegaz account for $66 \%$ of production and $57 \%$ of exports. Most shares in these companies are held by Russian banks, with the exception of Rosneft whose shares are all held by the State. Its share in production however is relatively marginal, at only $3.8 \%$.

Locatelli (C.), Finon (D.).- "L'échec du consensus de Washington dans une économie en transition: institutions formelles de marché et secteur de rente” Economie appliquée, 2004 (forthcoming), 28 p.

${ }^{10}$ The Loans for shares programme gave Russian banks control of some of the State's shares in the capital of the holding companies for three years in exchange for credit facilities. At the end of this period, the government could take back the shares in return for repayment of the loans. Otherwise the shares had to be repurchased definitively through a tender procedure, which was supposed to open up share trading in the companies. 
of rapidly increasing the value of their assets) and asset stripping ${ }^{11}$, behaviour which is not at all compatible with strategies to renew oil resources.

\section{- $\quad$ The volume of financing from foreign investors}

The spectacular rise in prices is boosting revenues and thus opening up greater possibilities of self-financing for Russia. However, given that the government's goals to diversify the economy imply using this extra revenue for other activities, this should nevertheless prompt the authorities to seek more financing from outside the country to develop the hydrocarbons sector, considered by foreign investors to be a more attractive investment option. In fact, the financing needed for oil industry investments is considerable, estimated by the IEA at \$328 billion for the period 2001-2030 $0^{12}$. Whereas before the arrival of Vladimir Putin oil sector privatisations had involved very little injection of foreign capital because of the ambiguous institutional and legal framework, now that the central authorities are gradually regaining control of the sector, the options and forms that foreign operator involvement might take will most likely become clearer ${ }^{13}$. In other words, a great many oil companies would be more reassured by OPEC type production sharing than by total privatisation with no guarantees from the Central State. The new international oil context in which supply will be subject to constraints in the coming years has changed the terms of the equation as far as capital from foreign investors is concerned. Although international oil companies generally prefer to be the operators, they could to a certain extent be satisfied with substantial though minority interests provided they are given more sound guarantees than those of the previous period. This is particularly true in view of the fact that they saw their profits and cash flow explode with the increase in prices. Moreover, it is becoming vital for them to boost their own reserves even though for the time being the OPEC countries have not yet fully opened their upstream sector to foreign investment.

\section{- $\quad$ Production tied to changes in international oil prices}

Maintaining certain stability in Russian oil production even at a level of $8 \mathrm{Mb} / \mathrm{d}$ implies developing oil-bearing areas that are less well known and not as easy to access, such as those of Timan Pechora and Eastern Siberia ${ }^{14}$. The gradual shift of the heart of production to these areas might well result in a substantial rise in production costs ${ }^{15}$. Russian production is by no

\footnotetext{
${ }^{11}$ Hoff (K.).- "The logic of Political Constraints and Reform With Application to Strategies for Privatization”.The World Bank, 4 December 2002, 39 p.

${ }^{12}$ In the document published by the Russian government in 2003 on the Russian Energy Strategy, required investments were estimated at \$230-240 billion for the period 2000-2020.

IEA-OECD, 2003, op. cit., p. 144-146.

${ }^{13}$ Locatelli (C.).- "The Russian oil industry between public and private governance: obstacles to international oil companies' investment strategies”. Energy Policy, 2004, (forthcoming), 17 p.

${ }^{14}$ Fontaine (J-M.), Laherrère (J.), Perrodon (A.).- "Le rebond de la production pétrolière en Russie: Quelles perspectives à long terme ? Quelles opportunités industrielles ?”.- Revue de l'Energie, n 538, July-August 2002, p. 421-432.

${ }^{15}$ Four main factors are likely to push up these costs: harsher climatic conditions, deterioration in quality of Russian reserves, necessitating the opening to production of smaller less productive deposits, the substantial investments required for opening up deposits in more difficult and more remote areas, and the inclusion of capital cost in the calculation, largely ignored under the soviet regime due to methods of calculating provision for depreciation. It is nonetheless true that there is - and will continue to be - considerable uncertainty surrounding the cost of producing oil from Russia's reserves.
} 
means insensitive to crude oil price levels. In fact, all of the "optimistic" production scenarios are conditional upon relatively high crude prices on the international markets.

- In the medium term, Russia's contribution to world incremental oil supply will disappear

Even with the most optimistic estimates, given the deposit depletion rates and current evaluations of recoverable and potential reserves, Russian output should level off at a maximum of $11 \mathrm{Mb} / \mathrm{d}$ after 2010. Russia would cover $12 \%$ of world crude demand as against $44 \%$ for OPEC (14\% for Saudi Arabia). With an output of $6 \mathrm{Mb} / \mathrm{d}$, its share would drop to $6.6 \%$. Admittedly this is an extreme scenario, but one that is not ruled out by certain analysts. Assuming that the reality will be somewhere in between, Russia's contribution to satisfying additional world demand will tend to drop and even disappear by 2010. This trend would be even more evident in the long term. According to the POLE model, in order to achieve equilibrium by 2030, OPEC's share should increase to 54\% and Saudi Arabia's to $19 \%$ while the share for the entire CIS zone (Russia and Caspian) should be around 10\%. Consequently, even assuming production of 11-12 $\mathrm{Mb} / \mathrm{d}$ in 2010, Russia cannot challenge OPEC's leadership in the long term.

Weight of CIS zone and OPEC on world oil scene

$\underline{2010 \text { and } 2030}$

$\mathrm{Mb} / \mathrm{d}$

\begin{tabular}{|l|c|c|}
\hline & 2010 & 2030 \\
\hline World crude oil demand & 90 & 121 \\
\hline OPEC supply of crude & 40 & 65 \\
\hline -incl. Saudi Arabia & 13.1 & 23.2 \\
\hline
\end{tabular}

Source: POLE-EPE.

\section{Russia is not insensitive to oil price levels}

Objectively, it is not in Russia's interest to oppose OPEC but rather to support (even indirectly) its price policy. Three factors argue in favour of such a strategy.

- First, changes in its oil production capacity

Prices condition the profitability of the Russian oil companies, the attraction of foreign investment and the financing of investments needed to renew reserves.

- Second, its economic growth

Economic growth was around 7.3\% in 2003 and is still largely driven by international hydrocarbon prices. According to a recent World Bank report, only high oil prices have in the past enabled Russia to achieve economic growth of over 5.5\%. A study by J. Rautava in 2002 
showed that a $10 \%$ rise in the price of oil would lead to an additional $2.2 \%$ increase in $\mathrm{GNP}^{16}$. According to Goohoon Kwon, IMF representative in Moscow, at least $80 \%$ of revenue gains were attributable to the hydrocarbons sector, the rise in oil revenues being directly linked to oil price increases ${ }^{17}$. The hydrocarbons sector has been a vital factor in the growth of Russia's revenues since the financial crisis of 1998. Furthermore, according to J.P. Pauwels and C. Swartenbroekx, risks related to less competitive prices for other (non-energy) exports due to a rise in the exchange rate (because of the oil price rise) remain very limited. Any drop in revenues from other exports would be more than offset by the increase in energy revenues (because of poor price elasticity in world demand for other exports) ${ }^{18}$. Finally, the Russian economy is far more sensitive to the volatility of international hydrocarbon prices than is officially recognised: according to the World Bank, the hydrocarbons sector represents 25\% of Russia's GNP and not 9\% as published in the official statistics by Goskomstat. Consequently, any price drop is extremely prejudicial to macro-economic equilibrium and thus to social stability. Conversely, a rise in prices results in a notable improvement in the country's situation, as we are witnessing at present ${ }^{19}$.

\section{- Third, gas policy support}

This is a decisive element given that oil product prices strongly influence the price of natural gas. If the price of oil drops below \$25, the return on certain Gazprom investments such as those in Yamal becomes problematic. Let us remember that its natural gas reserves and the development of these reserves are what give Russia an indisputable comparative advantage on the international hydrocarbons market. In fact, the country's already considerable gas exports (some 139 billion $\mathrm{m}^{3}$ per year to Europe) should continue to rise in the future (with exports of around 200 billion $\mathrm{m}^{3}$ per year by 2010). If Russia wants to play a strategic role in this sector - the means are available - relatively high oil prices are necessary for two reasons: first to ensure the profitability of the gas projects given the heavy transport costs involved, and second to finance the development of its gas reserves (notably those in Yamal and Eastern Siberia). The possibility of a more far-reaching international gas policy in Russia ${ }^{20}$ (that is, beyond the European market) is heavily dependent on oil price levels.

\section{Position vis-à-vis OPEC}

Because of its weight and its production maximisation policy, Russia can, in certain conditions - for example in the event of global surplus production capacity - influence oil prices. It must thus adopt a clear position with respect OPEC's price policy. Two options are possible and have been directly opposed over the last few years. The first, favoured by private

\footnotetext{
${ }^{16}$ Rautava (J.).- "The role of oil prices and the real exchange rate in Russia's economy”.- Bank of Finland, Institute for Economies in Transition, BOFIT, Discussion Papers, 2002, n³, 21 p.

${ }^{17}$ Goohoon Kwon.-“Budgetary impact of Oil Prices in Russia”.- IMF, 1 August 2003, 7p.

${ }^{18}$ Pauwels (J.P), Swartenbroekx (C.).- "La politique pétrolière russe: entre le G8 et l'Arabie Saoudite”.- Revue de l’Energie, $\mathrm{n}^{\circ}$ 537, June 2002, p. 366-379.

${ }^{19}$ The main consequence of Russia's high economic growth rate in 2003 was a significant decline in poverty levels. World Bank, (2004), op. cit., p. 11.

${ }^{20}$ Komarov (Y.).- "It’s a long time since we have been analyzing implications of gas market liberalization in Europe”.- Interviews, Gazprom, 20 January 2004, 5 p.
} 
Russian oil companies (at least those that export and/or are dominated by the banks), is characterised by cash stripping and asset stripping and is aimed at maximising exports in the very short term in order to rapidly increase the value of assets. This trend was sometimes publicly confirmed by officials close to these interest groups. It is a strategy that very nearly led Russia to oppose OPEC or at least to adopt the behaviour of a free-rider. The second option, advocated by some sections of the Russian government (certainly by Vladimir Putin), and probably by Gazprom, which has a strategic interest in high prices, leans more towards cooperation with OPEC. Opposition between these two trends reached a peak in 2002 and the difficulties experienced by President Putin in gaining acceptance for his approach probably influenced strategies to gain a firmer hold on the oil sector.

Given its financial requirements and macro-economic stakes and the improbability of OECD membership in the short term, Russia is not in a position to lead a prolonged price war or to accept low oil prices for too long a period. Furthermore, unlike Saudi Arabia, Russia does not have the room to manœuver that would enable it to play a role of swing producer. To be able to do this, it would need spare production capacity and the capability of rapidly increasing or decreasing its output in response to market conditions. Saudi Arabia knows perfectly well that its strength lies not so much in its production level in the absolute but in the volume of its spare production capacity. It can call this spare capacity into play to influence supply and is at present the only supplier (with OPEC) to have such a means of dissuasion at its disposal.

OPEC would lose some of its strategic importance, and possibly its "raison d'être", if for one reason or another it abandoned or could no longer maintain this (costly) policy of maintaining such a high spare capacity ${ }^{21}$. While Saudi Arabia has just confirmed its intention to maintain a spare capacity of 1.5 to $2 \mathrm{Mb} / \mathrm{d}$, this is neither envisaged nor conceivable in the case of Russia, which cannot afford to mobilise and freeze such resources for the purpose of stabilising the market ${ }^{22}$. Its attitude quite obviously puts it into the category price taker and free-rider.

We can thus understand the extent to which the future of Russia's oil policy is largely correlated with a policy in favour of defending prices. It is not in the country's interest to oppose OPEC and it does not have the means to do so because of the production cost differential in the event of a price war. Furthermore, with the tensions between world oil supply and demand, Russia is no longer concerned about its market share. Even a drop in demand would in the first instance concern OPEC which, until proved otherwise, remains the only swing producer. These developments suggest that in the coming years, if necessary, Russia's policy with regard to OPEC will be based at the very least on benevolent neutrality or even on carefully measured or more affirmative support, depending on circumstances, for example in the event of a price collapse.

\section{State regaining control of oil sector}

The Russian central authorities are moving back into the centre of the game. The energy sector policy will be used for the benefit of the centre and to the detriment of the oil

\footnotetext{
${ }^{21}$ Boussena (S.).- “Oil and market stability after 2004 ?”.- Middle East Economic Survey, 47 (40), 2004 pp. D1D5

${ }^{22}$ Boussena (S.).- "La nouvelle géopolitique pétrolière et les perspectives du marché".- Medenergie, (11), 2004 p. 7-10.
} 
companies and the regions ${ }^{23}$. The government is duty bound to maintain firm control over the evolution of oil production and reserves, and to control export strategies while avoiding any contribution to the lowering of international prices.

If in recent years the choice to expand production from existing deposits has placed the focus on the short term, the insistence of the Russian authorities on greater investment in exploration is an indication that more attention is being given to long-term development concerns in the new strategy. This could explain the downward revision of production estimates for 2003-2007 (9.5 Mb/d in 2007) ${ }^{24}$. The new oil policy appears to place greater importance on conserving deposits ${ }^{25}$ whereas until now the logic was based on maximising private company profits in the short term.

With this in mind, the State is aiming to reinforce its control of the sector while avoiding complete re-nationalisation of the oil industry ${ }^{26}$. More strict control over access to reserves ${ }^{27}$ should be detrimental to the interests of the regions while benefiting companies receiving government support (Gazprom, Lukoil, Surgutneftegaz, Rosneft) ${ }^{28}$. The State's discretionary reallocation of exploration and development licences to companies in which it holds majority shares (Rosneft, Gazprom) is an integral part of this process ${ }^{29}$. The proposed merger between Gazprom and Rosneft, is a mean to reinforce the Kremlin control over Gazprom (by increasing the State shares in Gazprom from about 39\% to 50\% plus one share). Is the takeover of Yungansknefetgaz (the Yukos main oil producer) the prelude to the creation of a big Russian state controlled (not necessarily owned) oil company ${ }^{30}$ ? It would then be a question of creating a "national champion" 31 or several national champions based on the

\footnotetext{
${ }^{23}$ The regions where the large hydrocarbon basins are located have until now had an important role to play because of the weakening of the Central State and the legislation adopted after the collapse of the USSR.

Mendras (M.), (under the direction of).- Comment fonctionne la Russie ? Le politique, le bureaucrate et l'oligarque.- CERI/Autrement, 2003, 122 p.

Vladimir Putin's recent decision to directly appoint governors without an elective process is part of this process.
}

24 “Moscou prévoit une croissance ralentie de la production d’hydrocarbures sur 2003-07”.- Pétrostratégies, 28 June 2004, p. 7.

25 “Russia Leans Closer To Opec Goals”.- Petroleum Intelligence Weekly, 5 January 2004, 2 p.

26 “Kremlin’s Hand Reshapes Oil Industry”.- Petroleum Intelligence Weekly, n 49, 8 December 2003, p. 1-2.; “Moscow flexes its muscles”.- Petroleum Economist, January 2004, p. 29-30.

${ }^{27}$ The more stringent conditions for obtaining a production sharing agreement are an illustration of this type of control.

Konoplyanik(A.).- "PSA debate not over”.- Petroleum Economist, July 2003 p. 12; Petroleum Economist, 19 July 2004, p. 9.

${ }^{28}$ Berniker (M.).-“Energy executives stand firm on Russia opportunities”.- Oil and Gas Journal, November 2003, p. 42-43.

In particular, the numerous special agreements negotiated by the Regions under Boris Yeltsin are increasingly being weakened by Vladimir Putin’s government.

${ }^{29}$ The re-allocation of licences for the Stockman, Talakan and Sakhaline III deposits are illustrations of this movement, as are the discussions on Gazprom's possible participation in the development of Kovytka.

30 « Moscow Tightens Its Grip With Yukos Auction ».- PIW, 3 january, 2005.

31 "Moscou crée un géant énergétique d’Etat, Gazpromneft, mais promet d’en ouvrir le capital”.- Pétrostratégies, 20 September 2004, p. 4-5. 
model currently developed by China where State policy is expressed through a number of public entities governed by a centralised strategy. This would be a new direction compared with the production associations of the previous soviet model.

With a similar logic and to weaken Regional powers, the various amendments to the Subsoil Law are changing the present system based on joint attribution (Federal-Local) of mining rights ${ }^{32}$. From now on, attribution of licences is the sole responsibility of the Federal State. The way in which the Russian government is currently handling the Yukos affair, and the positioning of Gazprom and Rosneft as principal actors in the hydrocarbons sector ${ }^{33}$, show the government's determination to control the sector for its own ends, whether at home or abroad. Finally, without wishing to confirm the previous regime of production sharing agreements (OPEC type), the Russian government still does not appear to be looking to a Norwegian type of system completely open to foreign companies. Clearly the Russian authorities hope to find an intermediate model that can attract foreign investment while enabling the Sate to be the deus ex machina of the procedure.

The government intends to maintain control over Russian oil company exports. This implies reinforcing its authority over export networks via Transneft, a state-owned company. Rivalry between Transneft and the Russian oil companies over pipeline routes implicitly involves the important stake of the export capacity of these oil companies. Construction of private pipelines that would be owned by the oil companies must therefore be limited as much as possible. Broadly speaking, strict control of development projects and existing export pipelines, enabling crude oil exports to be adjusted or limited as the need arises, gives more credibility to the official stance with respect to OPEC.

\section{Hydrocarbons at the service of the economy}

At the national level, the aim of economic growth announced by the government is accompanied by a second issue concerning the how the hydrocarbons rent is to be shared out between the main Russian players (State, private companies and consumers) ${ }^{34}$. Aware that the oil sector oligarchs have not, among other things, respected their commitments to reinvest their revenues in the oil sector, the central authorities seem to be favouring a policy with three aims: first, to redistribute some of the profits to consumers by keeping final energy prices relatively low, second, to feed more of the profits into the State budget through its tax system, and third to boost oil company investment in exploration.

\footnotetext{
${ }^{32}$ LeBoeuf, Lamb, Greene \& MacRae.- “Proposed Major Changes in Subsoil Laws”.- Russian Laws News, February 2004, 1 p.
${ }^{33}$ For example, the creation of a Gazprom-Rosneft-Surgutneftegaz consortium to tender in Eastern Siberia shows that the State intends to have a large stake in the development of this region, one of the main advantages of which are the nearby export markets in Asia. Similarly, the Russian State has undertaken discretionary reallocation of development and exploration licences to national companies Rosneft and Gazprom. The case of the Stokman deposit is an example.

${ }^{34}$ The battle between Yukos oil company president M. Khodorkovsky and the government is simply the outward manifestation of the desire of certain government officials to share out the oil rent differently. These officials belong in fact to the security services (ex-KGB now called the Federal Security Service), a group known under the name of siloviki, which counts among its members the Defence Minister S. Ivanov.

“Oligarchs Bow to Putin's New Deal”.- The Moscow Times, 17 November 2003, 2 p and "Defense Minister Tries on Energy Hat”.- The Moscow Times, 18 November 2003, 2 p.
} 
Generally speaking, the Russian authorities recognise that, objectively, the reforms introduced so far have not resulted in the creation of a mature market economy, with poor consolidation of ownership rights probably being the principal cause of this failure. Two uncertainties persist, the first concerning the right to use the assets (the transferability of ownership rights is not guaranteed, as shown by the Yukos affair ${ }^{35}$ and the second concerning access to resources, given the way in which the State is granting exploration and development licenses. While growth is driven by the hydrocarbons sector, the State has proved itself incapable of controlling the associated rent. In light of this situation, a new political consensus is emerging. The aim is still to set up a market economy, but through explicit use of the hydrocarbons sector.

\section{The international aspects of Russia's oil strategy: hydrocarbons as a geopolitical asset}

In addition to oil sector development, the policy of the Russian authorities appears to be increasingly aimed at setting up a coherent centralised strategy that instrumentalises the sector henceforth considered as providing a "comparative advantage" in international competition. The hydrocarbons sector, as well as being the main source of currency, would be explicitly called upon at a domestic and international level.

At the international level, it is a matter of Russia playing a geostrategic role - thanks to its hydrocarbons - enabling it to exert an influence in major international negotiations both with respect to the European market, where its influence is decisive, and the major Asian countries (Japan, China, South Korea) and, more recently, even the North American market. When we consider the increasingly important role of natural gas in the world energy market, Russia's role takes on another dimension. In a context where world energy supply is strongly constrained, Russia can see the opportunity of a strategic role, and one which cannot be ignored by the other major international actors. The Russians are seeking to exert an influence through their strong presence in the market to supply gas to the large European and Asian importers. Thus, Gazprom has now clearly established its intention of defining a truly global strategy ${ }^{36}$. It is a matter of maintaining or even increasing its market share in the European Union and positioning itself on the Asian and even the US markets. Not content to play on competition between Europe and Asia in its role as a reliable source of supply - for liquids and natural gas alike - Russia is even going so far as to exploit competition between the major Asian actors themselves in its programme to develop its reserves in Eastern Siberia. The competition between China and Japan related to the first Russian oil pipeline to Asia is an example. However, the recent statement concerning the final decision of the Russian authorities to choose the Japanese option by Nakhodak with the possibility of a branch to China shows ambiguous position of the Russian government. India is also interested by the Russian hydrocarbon resources and tries to acquire some interests in the development of

\footnotetext{
${ }^{35}$ A clearly defined property rights system is a system that guarantees the three elements involved in ownership of an asset: the right to use the asset (usus), the right to the returns from the asset, or more precisely, the right to appropriate the returns from the asset (usus fructus), and the right to sell the asset (abusus). This system of ownership rights is that of private ownership, which presupposes two essential characteristics: the exclusive nature of possession and transferability of rights.

Furubotn (E.), Pejovich (S.).- "Property Rights and Economic Theory: A survey of Recent Literature”. - Journal of Economic Literature, vol 10, $\mathrm{n}^{\circ}$ 4, December 1972 and Coriat (B.), Weinstein (O.).- Les nouvelles théories de l'entreprise.- Paris: Le livre de poche, 1995, 218 p.

${ }^{36}$ Komarov (Y.).- "It's a long time since we have been analyzing implications of gas market liberalization in Europe”.- Gazprom, 20 January 2004, 5 p.
} 
Sakhalin I. In fine, the Chinese banks has, recently, lend \$6 billion loan to facilitate the Rosneft's takeover of Yugansknefetgaz ${ }^{37}$.

Furthermore, with the globalisation of the natural gas markets, Russia can undoubtedly aspire to a decisive role in price formation for this commodity. In a context where there are tensions in world oil supply (and even gas supply in the case of the United States), Russia undoubtedly has a trump card to play in the context of the proposed "strategic partnerships".

From this point of view, hydrocarbons represent a structuring element in its foreign policy with CIS members, its "near abroad”, but also with the southern European countries and those of Eastern Europe. As part of their internationalisation strategy, the Russian companies, notably Gazprom and Lukoil, are increasing their presence in these areas by securing holdings in companies undergoing privatisation or through joint ventures ${ }^{38}$. This is particularly true in central Asia and the Caspian region, which enhances the complementarities (rather than the oppositions) between these two zones. The Russian State thus intends to "reinvest" the economic space of central Asia and expand its influence in the region ${ }^{39}$. This international policy could also explain the redeployment and multiplication of the interventions of the Russian oil companies (close to the State) in other oil producing regions, notably in the Middle East and North Africa ${ }^{40}$.

After wishing to rapidly adopt a privatisation model aimed at creating a mature market economy where the hydrocarbons sector would have been treated like any other sector, Russia now seems to want to give new direction to its economic strategy, especially since the beginning of Vladimir Putin's second mandate. The ultimate goal will still be to set up a market economy fully integrated in the world market. But realising that this goal cannot be achieved immediately, the government has decided that in a transition phase it will use the leverage power of hydrocarbons to help speed up the process. In doing this, Russia has adopted an approach not unlike that of OPEC. Although according to official discourse Russia is working towards a market model (in which use of the rent is not explicitly recognised), in actual practice Russia's development model is closer to that of certain OPEC countries, where hydrocarbons are used to accelerate economic development. Can this hybrid model, a sort of

\footnotetext{
37 « Chinese Lend Rosneft \$6 Bln for Yugansk ».- The Moscow Times, 2, janvier 2005.

38 “Broadening export strategy”.- Petroleum Economist, May 2004, p. 21-23.

${ }^{39}$ It is very difficult to identify the connections between Vladimir Putin's foreign policy and the strategies of the Russian energy companies. But as R. Legvold underlines, it is obvious that the interests acquired by certain of these companies in pipelines, refineries and deposits in central Asia are in line with Vladimir Putin's intentions to increase his influence in this zone. Different cooperation organisations bringing together Russia and countries of central Asia (Kazakhstan, Kyrgyzstan, Turkmenistan) have thus sprung up. The Shanghai Cooperation Organisation is one such organisation. Note also that in September 2004 Russia became a member of the Central Asian Cooperation Organisation. This may be a forerunner to stronger business development between these countries and a new strategic influence by Russia in "near abroad" countries.

Legvold (R.).- "Russia’s Unformed Foreign Policy”.- Foreign Affairs, n 5, September-October 2001, p. 70.

${ }^{40}$ For example, the "energy pact" signed between Russia and Saudi Arabia in September 2003 following the visit of Prince Abdullah Bin Abdel-Aziz to Moscow is expected to lead to a certain number of joint projects and the participation the Russian companies (Gazprom, Lukoil) in development of the gas sector in Saudi Arabia. “Saudi Pact Shows Russia’s New Strength”.- Petroleum Intelligence Weekly, n 36, 8 September 2003, p. 1-2.
} 
third option combining the two models mentioned above, serve as a form of governance for the hydrocarbons sector in the transition phase and enable the real integration of Russia in the G8?

\section{Bibliography}

Berniker (M.).-“Energy executives stand firm on Russia opportunities”.- Oil and Gas Journal, November 2003, p. $42-43$.

Boussena (S.).- “Oil and market stability after 2004?”-- Middle East Economic Survey, 47 (40), 2004, pp. D1-D5

Boussena (S.).- "La nouvelle géopolitique pétrolière et les perspectives du marché”.- Medenergie, (11), 2004, p. 7-10.

“Broadening export strategy”.- Petroleum Economist, May 2004, p. 21-23.

“Chapter 9: Russia-An in Depth Study” in World Energy Outlook 2004, draft IEA-OECD, September 2004

Coriat (B.), Weinstein (O.).- Les nouvelles théories de l'entreprise.- Paris: Le livre de poche, 1995, 218 p.

“Defense Minister Tries on Energy Hat”.- The Moscow Times, 18 November 2003, 2 p.

Fontaine (J-M.), Laherrère (J.), Perrodon (A.).- "Le rebond de la production pétrolière en Russie: Quelles perspectives à long terme ? Quelles opportunités industrielles?”.- Revue de l'Energie, n 538, July-August 2002, p. 421-432.

Furubotn (E.), Pejovich (S.).- "Property Rights and Economic Theory: A survey of Recent Literature”. - Journal of Economic Literature, vol 10, n 4, December 1972.

Goohoon Kwon.-“Budgetary impact of Oil Prices in Russia”.- IMF, 1 August 2003, 7p.

Hoff (K.), Stiglitz (J.).- "After the Big Bang ? Obstacles to the Emergence of the Rule of Law in PostCommunist Societies”.- World Bank Policy Research, Working Paper 2934, December 2002, 44 p.

Hoff (K.).- "The logic of Political Constraints and Reform With Application to Strategies for Privatization”.- The World Bank, 4 December 2002, 39 p.

Khartukov (E.), Starostina (E.).- "Ex-Soviet Oil Exports: Are the Russians really Coming”.- MEES 47:4, 26 January 2004, $10 \mathrm{p}$.

Komarov (Y.).- "It's a long time since we have been analyzing implications of gas market liberalization in Europe”.- Gazprom, 20 January 2004, 5 p.

Konoplyanik(A.).- “PSA debate not over”.- Petroleum Economist, July 2003 p. 12

“Kremlin’s Hand Reshapes Oil Industry”.- Petroleum Intelligence Weekly, n 49, 8 December 2003, p. 1-2.

LeBoeuf, Lamb, Greene \&MacRae.- "Proposed Major Changes in Subsoil Laws".- Russian Laws News, February 2004, 1 p.

Legvold (R.).- “Russia’s Unformed Foreign Policy”.- Foreign Affairs, nº 5, September-October 2001, p. 70.

Levy (B.), Spiller (P.) (Eds).- Regulations, Institutions and Commitment.- Cambridge University Press, 1996.

Locatelli (C.).- "The Russian oil industry between public and private governance: obstacles to international oil companies' investment strategies”. Energy Policy, 2004, (forthcoming), 17 p 
Locatelli (C.), Finon (D.).- "L'échec du consensus de Washington dans une économie en transition: institutions formelles de marché et secteur de rente.” Economie appliquée, 2004 (forthcoming), 28 p.

Mendras (M.), (sous la direction de).- Comment fonctionne la Russie ? Le politique, le bureaucrate et l’oligarque.- CERI/Autrement, 2003, 122 p.

“More Oil Taxes on the Way”.- The Moscow Times, 7 July 2004.

« Moscow Tightens Its Grip With Yukos Auction ».- PIW, 3 january, 2005.

Lambert (T.), Woollen (I.).- "View of 12 million b/d Russian output by 2010 places focus on export limits”.- Oil and Gas Journal, 26 July 2004, p. 32-38.

“Moscou crée un géant énergétique d’Etat, Gazpromneft, mais promet d’en ouvrir le capital”.- Pétrostratégies, 20 September 2004, p. 4-5.

“Moscow flexes its muscles”.- Petroleum Economist, January 2004, p. 29-30.

“Moscou prévoit une croissance ralentie de la production d’hydrocarbures sur 2003-07”.- Pétrostratégies, 28 June 2004, p. 7.

“Oligarchs Bow to Putin’s New Deal”.- The Moscow Times, 17 November 2003, 2 p.

Pauwels (J.P), Swartenbroekx (C.).- "La politique pétrolière russe: entre le G8 et l'Arabie Saoudite".- Revue de l'Energie, n 537, June 2002, p. 366-379.

Petroleum Intelligence Weekly, 19 July 2004, p. 9.

“Putin seizes Yukos shares; Yukos names new CEO” OGJ, 10 November 2003

Roland (G.).- Transition and Economics: Politics, Markets, and Firms.- The MIT Press, 2000, 400 p.

“Russia Leans Closer To Opec Goals”.- Petroleum Intelligence Weekly, 5 January 2004, 2 p.

“Russian Economic Report”.- World Bank, n7 February 2004, 22 p.

"Russian Economy: Trends and Perspectives”. Institute for The Economy in Transition, Monthly Bulletin, September 2003 and July 2003.

Rautava (J.).- “The role of oil prices and the real exchange rate in Russia’s economy”.- Bank of Finland, Institute for Economies in Transition, BOFIT, Discussion Papers, 2002, n³, 21 p.

“Saudi Pact Shows Russia’s New Strength”.- Petroleum Intelligence Weekly, 8 September 2003, p.1-2.

Shleifer (A.), Vishny (R.).- The Grabbing Hand - Government Pathologies and their Cures.- Cambridge, MA: Harvard University Press, 1998.

Tompson (W.).- Putin and the 'Oligarchs' A two-Sided Commitment Problem.- The Royal Institute for International Affairs, Prospects For The Russian Federation Project, REP BN 04/03, August 2004, 16 p.

“World Energy Investment Outlook 2003”.- IEA-OECD, 2003, p. 148.

“World Energy Investment Outlook 2002”.- IEA-OECD, 2002, 530 p. 